\title{
Fiscal Deficits and Executive Planning Horizons
}

\author{
Mike Seiferling ${ }^{\dagger}$ \\ $\dagger$ Lecturer/Assistant Professor of Public Finance \\ University College London \\ 29/31 Rubin Street, London UK \\ WC1H 9QU \\ m.seiferling@ucl.ac.uk
}

\begin{abstract}
Executive control of government is generally not a long-term job. In such cases, relatively short executive tenure should be expected to play an important role in determining the degree to which policymakers internalize the future costs associated with their current fiscal behavior. The effects of policymaker's expected planning horizons on macroeconomic outcomes, however, have been difficult to model outside of a fixed term limit context due to the unobserved likelihood of remaining in office, along with potential endogeneity problems where re-election campaigns can be enhanced with generous, deficit financed expenditures in election years. From a globally representative sample of 79 countries over a 32 year period (1980-2012), this paper provides empirical evidence suggesting that incumbent governments who know that will not be in office in the following period with a probability of one, are found to generate significantly higher deficits in a linear discounting model, and are found to produce the least responsible fiscal outcomes where the likelihood of re-election is around fifty percent in quadratic discounting models.
\end{abstract}

Keywords: fiscal performance; executive planning horizons; political business cycle

JEL Classification: H1, H3, H6 


\section{Introduction}

Historically unprecedented increases in the use of peacetime deficit financing has led to a persistent accumulation of government debt throughout the 1970 s into the $21^{\text {st }}$ century in both advanced and emerging economies. The financial crisis of 2008 amplified the cumulative effects of this borrowing, with gross government debt to GDP ratios reaching well over 100 percent in many advanced economies, yet, austerity efforts remain a slow, variable, and politically difficult, process. In order to better explain the large degree of cross-country variability in fiscal performance, a great deal of literature has explored institutional and behavioral features of the financial decision making process in government (Barro 1973; Roubini and Sachs 1989; Poterba 1996 Perotti and Kontopoulos 2002). Tsebelis's veto-players, and Weingast and Shepsle's application of the tragedy of the commons/common pool resource, problem have been shown to generate significant negative effects on fiscal outcomes through inefficiencies created in the budget process (Weingast, Shepsle and Johnsen 1981; Roubini and Sachs 1989; Franceze 2007, 2009; Alesina et al 1999; Tsebelis and Chang 2004; Hallerberg et al. 2007, 2009; Wehner 2010). Theoretical and empirical applications have also emphasized slow adjustment effects generated by large numbers of veto players, as well as suboptimal budget size and debt accumulation, from the 'Law of $1 / N$ '.

There have also been a small collection of theoretical and empirical contributions considering finite planning horizons of politicians, where exogenous or probabilistic tenure is expected to generate negative inter-temporal consequences for fiscal outcomes, as political actors fail to fully internalize the costs of future burdens, or use them strategically against their successors (Alesina and Tabellini 1989; Persson and Svensson 1989; Besley and Case 1995; Debrun and Kumar 2007). The potential endogeneity of expected tenure (governments pursuing deficit spending to 
increase probability of re-election) has, however, made it difficult to estimate these discount rate effects on fiscal performance outside of a fixed term limit framework (i.e. US states - see Besley and Case 1995; Carey 1996; Alt and Rose 2009).

Using a large and globally representative unbalanced panel of 79 countries over a 32 year period (1980-2012), this paper is the first to empirically test for the effects of latent finite planning horizons (probabilistic tenure) on fiscal balances. This is accomplished by using expected electoral loss probabilities based on the recent work of Kayser and Lindstadt (2015). The findings confirm Barro's tax smoothing theory, and show further evidence of both temporal and inter-temporal fragmentation effects predicted by the common pool resources problem literature. With respect to planning horizons, incumbent governments who know that will not be in office in the following period with a probability of one, are found to generate between $0.64 \%$ and $1.05 \%$ higher deficits (as a $\%$ of GDP) in a linear discounting model, and are found to produce the least responsible fiscal outcomes where the likelihood of re-election is around fifty percent in quadratic discounting models. These results compliment the work of Debrun and Kumar (2007) who find that government stability has a significant effect on cyclically adjusted primary balances in a sample of eighteen EU countries over the 1990 - 2004 period. The significance of these findings raises questions about the propensity for policymakers to behave with fiscal irresponsibility as a result of the most fundamental aspect of democratic institutions: executive transitions.

Part 2 of this paper will discuss existing literature on fiscal deficits and finite planning horizons of policymakers. The data will be reviewed in part 3, and Part 4 will test for within-country effects of probabilistic tenure on fiscal performance taking into account the difficulties that come with unobserved transition probabilities. Part 5 will conclude. 


\section{Fiscal Deficits and Executive Planning Horizons}

From previous literature, there are at least two ways in which to formally characterize the relationship between expected executive tenure and fiscal performance. Firstly, where incumbent governments face an exogenously given probability of being in office at time $t+1$ which is less than unity, the likelihood that they will use public debt as an instrument to influence successive administrations discretionary budgeting powers is expected to increase (Alesina and Tabellini 1989; Persson and Svensson 1989; Devereux and Wen 1998; Debrun and Kumar 2007). This should lead to larger fiscal deficits in years where there exists a high expected probability that the executive in office in period $t$, will not be in office in period $t+1$. Secondly, it is possible that the same executive may attempt to use fiscal policy as a campaigning devise, increasing government expenditures in years where the probability of a transition is high in order to 'buy back' myopic voters. These two scenarios make it difficult to separate out whether a defeated executive generated high levels of debt to constrain their successor, or, a winning executive was successful because of deficit financed increase in political support. From a theoretical perspective, an easy solution would be to exogenously fix the probability of remaining in office in order to concentrate on the fiscal discount effect with comparative statics.

Alesina and Tabellini take on such an approach proposing a model where citizen disagreement, rather than myopia, influences fiscal policy in democracies. Two parties are assumed to choose the same levels of taxation and public consumption (private consumption-leisure tradeoff are equal under both parties), but differ with respect to preferences for the composition of public goods. The incumbent government's objective functions is time separable into an intra-period

problem of choosing taxes and provision of public goods for a given deficit (static), and, an intertemporal problem of choosing the size of the deficit (dynamic). This inter-temporal fiscal 
decision is influenced by the (exogenous) probability of the executive remaining in office in future periods as well as the distance between the preferences of incumbents and successor administrations. For example, a conservative incumbent who knows with a high probability that they will lose power to a liberal successor, can strategically use deficit spending on their preferred composition of expenditures in order to constrain their successors ability to provide its preferred composition. In equilibrium, policymakers set their marginal utility of leaving debt to the future equal to the time discounted expected marginal cost of inheriting that debt tomorrow. This implies that incumbents, who have low expectations of inheriting future debt, will fail to internalize the inter-temporal distortions created by running large deficits. Governments who discount the future at higher rates than the general public will run larger than optimal deficits in order to increase expenditure on their preferred bundle of public goods at time $t$ while constraining future governments from spending on their less preferred compositions at time $t+1$. Alternatively, a social planner with infinite horizons (re-appointed with probability of one), adopts a social welfare maximizing weighted average of the preferences of the citizens and balance the budget in every period (Alesina and Tabellini 1990). From this, it should be expected that high degrees of polarization between party preferences, and low levels of probabilistic executive tenure to generate sub-optimal fiscal outcomes and relatively higher levels of equilibrium debt (ceteris paribus).

Persson and Svensson (1989) take on a similar approach, but assume policymakers to possess different preferences for the level, rather than composition of, government expenditure. Finite horizon governments are confronted with a trade-off between two types of distortions: volume distortions, which occur where government consumption is higher than the optimal level preferred by that government, and; inter-temporal distortion, which occurs where, for a given 
level of public consumption, the time profile of taxes differs from the ex-ante optimum solution. Assuming that policymakers are forward looking, strategic, and the volume of inherited debt has an effect on newly elected governments taxation and spending decisions, 'stubborn' incumbents who put a significant amount of weight on minimizing volume distortions relative to intertemporal distortions should be expected to borrow more than it would if it had infinite planning horizons (Persson and Svensson 1989). This is to say that governments who know with some non-zero probability that they will hand over power to a new administration with different preferences for levels of government consumption, will chose to leave a deficit/surplus in order to force its successor to spend less (in the case of a conservative government) or more (in the case of a liberal government). Again, the ideological distance between current and expected future incumbents, as well as probabilistic tenure of the current executive, are both expected to generate significant distortionary effects on fiscal outcomes.

Treating the probability of remaining in office in the next period as exogenously given assumes away the possibility that it is partially dependent on fiscal behavior of the incumbent, which can influence the longevity of their tenure in office (Weingast, Shepsle, and Johnsen 1981; Ferejohn and Krehbiel 1987; Dewan and Myatt 2010). For example, policymakers may use deficit financing strategically to increase their perceived relative performance in close elections (MilesiFerretti and Spolaore 1994) or may 'bring home the bacon' by securing discretionary earmarked funds for their constituencies (Stratmann 2012). In order for this phenomenon to hold there must exist some degree of fiscal illusion, and/or a low degree of fiscal transparency, where voters do not fully internalize the inter-temporal budget constraint of the government and therefore overestimate the benefits of current expenditures relative to the future tax burden (Alt and Lassen 2006). Opportunistic office seeking politicians can take advantage of this illusion/lack of 
transparency by deficit financing new spending (without increasing taxation) in order to buy public support in years where the probability of an executive transition is high (Alesina and Perotti 1995). The probability of being in office in the next period, and thus the degree to which policymakers internalize future distortionary burdens, can therefore both affect, and, be affected by, fiscal outcomes. Political parties will discount the future to the extent that they believe they will no longer be in power, however, their likelihood of remaining in power can be influenced by expansionary fiscal policy. This endogeneity problem has made it difficult for researchers to measure the effects of expected tenure (outside of a fixed term limit context) on fiscal outcomes. Where incumbents use fiscal maneuvering as a strategic device to win an election, we would expect deficits to be highest in the midst of close elections where both incumbent and opposition parties stand a good chance of winning, whereas; for incumbents who form their fiscal policy based on expectations of future tenure in the executive, we would expect high deficits where the likelihood of re-election is very low.

The small number of empirical contributions thus far have either worked within the context of fixed term limits (Besley and Case 1995; Carey 1996; Zupan 1991; Alt and Rose 2009) or have ignored the endogeneity of expected tenure, focusing instead on exogenously given levels of government stability or average tenure (Debrun and Kumar 2007; Edwards and Tabellini 1991) From a fixed term limit context, Besley and Case (1995) find evidence that exogenously imposed term limits have a significant effect of fiscal policy outcomes in US gubernational elections over the 1950-1986 period. The results suggest that governors who are ineligible to stand for election in the following period are found to generate higher levels of sales taxes (7-8 \$ per capita on average), income taxes ( $9 \$$ per capita on average) and state expenditure ( $15 \$$ per capita on average). Alt and Rose (2009) build on these results within the context of US elections across 
forty-five US states between 1974 and 1999 in a principal-agent framework which considers the relationship between real fiscal outcomes and two focal areas of 'incentives' and 'ability'. Their results suggest that states, whose approval rating ranges between $40-60$ percent $^{1}$, show a statistically significant pattern of per capita spending which is estimated to be $38 \$$ higher in election years (relative to midpoint of election cycle). Outside of a fixed term limit framework, Debrun and Kumar (2007) find evidence from a sample of 18 European Union economies over the 1990-2004 period, that decreases in government stability (which they dub a "plausible proxy of the risk faced by an incumbent of being voted out") generates negative effects on cyclically adjusted primary balances (CAPB) to the extent that very unstable governments will, on average, run one percent of GDP higher CAPB than very stable ones (ceteris paribus). Finally, Edwards and Tabellini (1991) find some support for a positive relationship between fiscal deficits and the frequency of government changes for a sample of 42 developing countries between 1963-1988, validating the theoretical expectation that "the policymaker may wish to borrow in excess of the optimum, and let his successor 'pay the bills'."

The central theme in all of these studies is the importance of finite horizon policymakers whose interest in optimal future fiscal outcomes is influenced by the expected probability that they will be in office in time $t+1$. The theoretical contributions suggest two possibilities: $i$ ) as this probability increases, incumbent executives are more likely to internalize the future costs of deficit financing by generating responsible fiscal outcomes (linear), and, $i i$ ) where this probability approaches fifty percent, incumbent executives may attempt to win the election via expansionary/irresponsible fiscal policy (non-linear). Although little is known about the empirical validity of these models (Besley and Case 1995), the sparse evidence thus far has

${ }^{1}$ Based on polling data. 
suggested that finite planning horizon effects do exist in the same direction as predicted in the theoretical literature, but have not pinned down whether they are based on discount factors (linear effects) and/or are used strategically to win elections (quadratic effects).

Lastly, some of the problems associated with short political horizons in fiscal policymaking have been shown to be dampened with the existence of well-defined budget rules (Von Hagen and Harden 1995; Poterba 1996; Alesina et al. 1999; Volkerink and De Haan 2001; Hallerberg et al. 2007, 2009; IMF 2009, 2012, 2014, 2015, 2017; Wehner 2010, IMF 2012, IMF 2017). Along with fiscal councils and strong monitoring, these have become popular devices for counteracting deficit biases, and achieving greater levels of fiscal responsibility. Based on this literature, it is possible that the existence of fiscal rules may help in reducing fiscal indiscipline associated with short executive planning horizons.

\section{The Data}

Data on GDP growth, unemployment, inflation and interest rates was taken from the World Banks World Development Indicators (WB-WDI) for the years 1980-2012. ${ }^{2}$ Consolidated central government deficits/surplus figures were computed from International Monetary Fund

Government Finance Statistics Yearbook for the years 1980-2012.3,4 With respect to political variables, selection was limited by the scope of the analysis. Ideology is classified into one of three categories of left right and center (see World Bank - Database of Political Institutions (DPI) 2012, p.6-7 for definitions) which is used to compute government polarization as the maximum

\footnotetext{
${ }^{2}$ In cases where data for unemployment and inflation was missing from WDI but available from either the OECD or IMF World Economic Outlook database, we replace the missing cells with this data.

${ }^{3}$ For countries who reported fiscal data using accrual accounting, net lending/borrowing is treated as synonymous with deficit/surplus throughout this paper.

${ }^{4}$ Government deficit/surplus data was missing from IMF Government Finance Statistics Yearbook for Australia for the years 1995-1998 which we replace with National Accounts data from the OECD.
} 
distance (using the left, center, right classification) between the executive party and the three largest parties in government. Fragmentation is measured using the effective number of parties in the executive.

Theoretical findings also suggest that ideological affiliation of opposition parties should be expected to play a role in the fiscal decisions of the executive where there is a divergence between the party currently in power and the party most likely to take office should the incumbent lose (i.e. left executive and right opposition, or vice-versa). Where the executive expects that a transition of power will also be a transition of government ideology, we might expect different fiscal behavior, relative to a transition of power without a change in government ideology (Alesina and Tabellini 1989, Persson and Svensson 1989; Testa 2010). In order to capture this effect, a variable is computed as the difference between executive ideology and the ideology of the main opposition party (both measured on a three-point scale). An additional binary variable is then computed equaling one where there is an executive transition and the losing incumbent party is predominantly affiliated with liberal/conservative ideology while the new executive is affiliated with conservative/liberal ideology (zero otherwise). The raw data for this variable is taken from DPI and the variables are coded by the author. Data for fiscal rules (debt and balanced budget) was sourced from the IMF's Fiscal Rules Database. ${ }^{5}$

With respect to a continuous measure of loss probabilities, this paper relies on a modified version of the Kayser-Lindstadt method which characterizes unobservable probabilities of a swing in power between the largest and second largest party in a government during an election year as:

\footnotetext{
${ }^{5}$ Data can be downloaded directly from: http://www.imf.org/external/datamapper/fiscalrules/map/map.htm
} 


$$
s_{t}=\left(\Delta v_{1 t}\right) \eta_{1}^{*}-\left(\Delta v_{2 t}\right) \eta_{2}^{*}
$$

Where $\Delta v_{q t}$ measures the vote share difference for party $q$ between time $t+1$ and time $t$ : $\left(v_{q, t+1}-v_{q t}\right)$, and, $\eta_{q}^{*}$ measures the (time constant) vote-seat elasticities. ${ }^{6}$ Given that $v_{q, t+1}$ is unknown and unobservable for each district, the authors map past swings from previous periods beginning at $n=1$ through $t$ - 1 , into a loss function which is used to estimates the probability of an electoral swing $\left(g:\left\{s_{n}\right\}_{1}^{t-1} \rightarrow f(s)\right)$. The sparsity of elections over a relatively short time period, lead the author to smooth the series via a standard normal kernel density function: $K_{\varnothing}(s)=\phi(s)$. From this, it is possible to estimate the probability of a plurality shift as:

$$
\operatorname{pplur}_{i t}^{*}=\int_{-\infty}^{-S_{i n c}} K_{\emptyset}(s) d s
$$

Where $S_{\text {inc }}$ is the proportional advantage in seats held by the incumbent party relative to the largest opposition party $\left(S_{i n c}=\frac{s_{i n c}-s_{o p p}}{s_{i n c}+s_{o p p}+\sum_{i=3}^{T P-2} s_{i}}\right.$; where, $T P=$ total parties in parliament $)$. See Kayser and Lindstadt (2015) for more detailed discussion. Within this paper, feasible options for votes shares $\left(v_{1 t} \text { and } v_{2 t}\right)^{7}$ in our broader sample of countries, were computed as: $a$ ) aggregate vote shares of the largest governing party minus largest opposition party, or: $b$ ) aggregate vote shares of the entire governing coalition minus the combined opposition vote shares (where this differs from $a)$ ). Standard normal kernel density functions $K_{h}(s)$ for both $a$ ) and $b)$ were then estimated. From this, $p p l u r_{i t}^{*}$ estimates can be easily computed given threshold values computed using $S_{i n c}, S_{o p p}$, and $\sum_{i=3}^{T P-2} S_{i}$. To get an idea of the relationship

\footnotetext{
${ }^{6}$ For example, in a two party system where $\eta_{q}^{*}=1(q=1,2)$ and party 1 gains 10 seats while party 2 loses 10 seats, our swing $\left(s_{t}\right)$ would be 20 .

${ }^{7}$ See Appendix A.
} 
between the two measures, Figure 1 belw shows a simple scatter plot between the K-L district level data and the aggregate estimates from our $a$ ).

Figure 1: Aggregate and District Level Kayser-Lindstadt Loss Probabilities

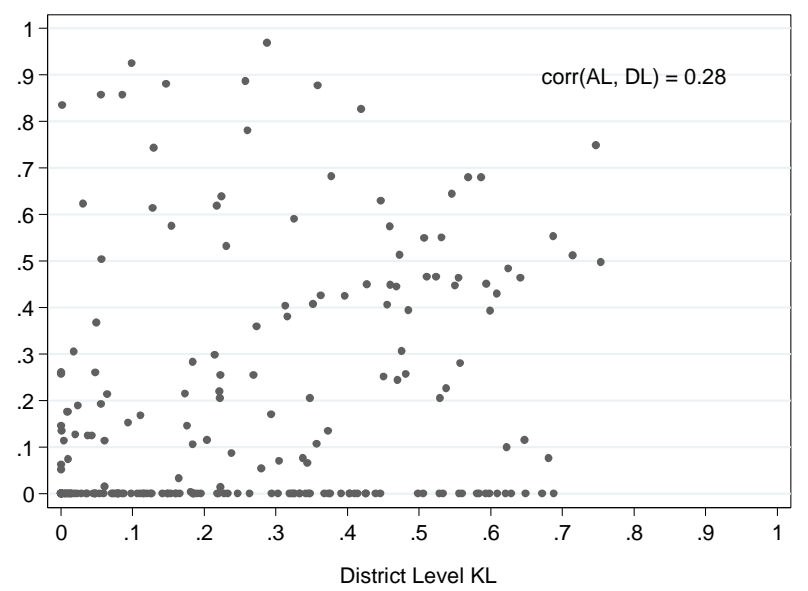

Source: Kayser-Lindstadt (2015) and authors calculations

As expected, the aggregate measure of loss probabilities is skewed towards zero given the narrower domains on which the likelihoods are estimated. Effectively, this means that the district level densities will give some non-zero probability of executive turnover to very unlikely swings while the aggregate levels densities will assign these zero probabilities. There was sufficient information on all dimensions for a globally representative unbalanced panel of 83 countries spanning the 1980-2012 period. A list of variables and summary statistics is available in Appendix B.

\section{Estimation}

This paper begins with a standard fixed effects model, regressing central government fiscal balances on a common set of tax smoothing and political variables, including fiscal rules and the binary event of an election. Common pool resource and veto player theory suggest that, both size, and fragmentation should have directional (temporal) and volatility (inter-temporal) effects 
on government balances (Tsebelis 2002; Chang and Tsebelis 2004; Franzese 2007). In the case

of the common pool resource problem, we should expect an increase in the number of

meaningful actors in the budget process to increase the temporal deficit bias of government as

these actors fail to fully internalize the cost of their decisions. We should also expect that, as

more decision makers are included in the budget process, the likelihood of a consensus move

away from the status quo will decrease, making it more difficult to implement intertemporal

changes in fiscal outcomes (Chang and Tsebelis 2004; Franzese 2010; Blais et al. 2010). ${ }^{8}$ From

this, the equation for central government surplus can be specified as: ${ }^{9}$

$$
y_{i t}=\alpha_{i}+\delta\left(\text { elec }_{i t}\right)+\boldsymbol{P}_{i t} \boldsymbol{\beta}+\boldsymbol{X}_{i t} \boldsymbol{\theta}+\varepsilon_{i t}
$$

Where $y_{i t}$ is the surplus/deficit or net lending/borrowing as a percentage of GDP in country $i$ at time $t$ and $\alpha_{i}$ is an unobserved intercept for country $i$. The first term on the right hand side is a binary indicator equaling one in years where an executive election taking place. ${ }^{10} \boldsymbol{P}$ and $\boldsymbol{X}$ are matrices capturing all other political and macroeconomic determinants, respectively, including intertemporal effects ${ }^{11}$ and the existence of balanced budget and debt rules, on central government fiscal balances. $\delta, \rho_{l}, \rho_{i}, \boldsymbol{\beta}$, and $\boldsymbol{\theta}$ are unknown parameters/vectors of parameters to be estimated.

\footnotetext{
${ }^{8}$ Effectively, this means that we should expect $i$ ) larger deficits in countries with larger and more fractionalized sets of meaningful decision makers in the budget process, and $\mathrm{ii}$ ) slower adjustments as the number of veto players and their ideological distance increases.

${ }^{9}$ It should be noted that electoral system are not included in equation (1) as these are absorbed in the country fixed effects (as is the case of any other time invariant country characteristics over the sample period).

${ }^{10}$ This variable equals one where there is a parliamentary election in parliamentary systems or where there is a presidential election in a presidential system (source: WB-DPI)

${ }^{11}$ Specifically, this includes central government balances lagged by one period $\left(y_{i t-1}\right)$ and interaction term between lagged central government balances and parties in government (pig). This interaction term is measured with absolute values of central government balances as veto player theory argues that as their numbers of meaningful actors increases, this should constrain the magnitude, not direction, of year-on-year changes in fiscal performance (Tsebelis 2002; Chang and Tsebelis 2004; Franzese 2007, 2010) This is a slight modification from the specifications in Franzese (2007, 2010) and Blais et al (2010), but is consistent with their theoretical expectations (See Blais et al. (2010) Figure 1). Note that the inclusion of an intercept term would have multicollinearity issues (with lagged central government balances). The exclusion of an intercept term effectively assumes that it is zero, which was confirmed by the data.
} 
The results from three specifications are given below in Table 1. The first and second build on past theoretical and empirical findings from equation (1). The third specification includes three additional indicator to test the Persson and Svensson (1989) hypothesis that ideological differences between the incumbent and opposition party will lead incumbents to 'restrain' future policy options. The first two indicators are binary variables representing right and left wing executives (relative to center). The third indicator measures the ideological distance between the executive branch of government and the largest opposition party on a three-point scale (left/center/right). For example, where the executive is predominantly right (left) wing and opposition is predominantly left (right) wing, this indicator will take on a value of -3 (3), while a left executive-left opposition or right executive - right opposition combination would produce a value of zero. 
Table 1: Within Country Determinants of Central Government Balances (1980-2012) (Fixed effects with cluster robust standard errors in parenthesis)

\begin{tabular}{|c|c|c|c|}
\hline \multirow[t]{2}{*}{ Variables } & \multicolumn{3}{|c|}{ Central Government Balances (\%GDP) } \\
\hline & (1) & (2) & (3) \\
\hline $\begin{array}{l}\text { Central Government Surplus/Deficit }(t-1) \\
(\% G D P)\end{array}$ & $\begin{array}{l}0.41 * * * \\
(0.06)\end{array}$ & $\begin{array}{l}0.52 * * * \\
(0.03)\end{array}$ & $\begin{array}{c}0.51 * * * \\
(0.05)\end{array}$ \\
\hline $\begin{array}{l}\text { Central Government Surplus/Deficit } \\
(t-1)^{* \text { Polarization }}\end{array}$ & $\begin{array}{c}0.06 \\
(0.05)\end{array}$ & & \\
\hline $\begin{array}{l}\text { Central Government Surplus/Deficit }(t-1) \\
\text { *Parties in Government }\end{array}$ & & $\begin{array}{c}0.09 * * * \\
(0.03)\end{array}$ & $\begin{array}{c}0.09 * * * \\
(0.03)\end{array}$ \\
\hline GDP growth & $\begin{array}{c}0.25^{* * *} \\
(0.03)\end{array}$ & $\begin{array}{c}0.24 * * * \\
(0.03)\end{array}$ & $\begin{array}{c}0.24 * * * \\
(0.03)\end{array}$ \\
\hline Inflation (ln) & $\begin{array}{l}0.18^{*} \\
(0.10)\end{array}$ & $\begin{array}{l}0.17^{*} \\
(0.10)\end{array}$ & $\begin{array}{c}0.12 \\
(0.10)\end{array}$ \\
\hline Unemployment & $\begin{array}{l}-0.08^{*} \\
(0.04)\end{array}$ & $\begin{array}{l}-0.07 * \\
(0.04)\end{array}$ & $\begin{array}{l}-0.10^{* *} \\
(0.04)\end{array}$ \\
\hline Real Interest Rate & $\begin{array}{l}-0.01 \\
(0.01)\end{array}$ & $\begin{array}{l}-0.01 \\
(0.01)\end{array}$ & $\begin{array}{l}-0.01 \\
(0.02)\end{array}$ \\
\hline Polarization & $\begin{array}{l}-0.12 \\
(0.18)\end{array}$ & & \\
\hline Parties in Government & & $\begin{array}{c}-0.25^{* *} \\
(0.10)\end{array}$ & $\begin{array}{c}-0.23 * * \\
(0.09)\end{array}$ \\
\hline Executive Election & $\begin{array}{c}-0.37 * * * \\
(0.11)\end{array}$ & $\begin{array}{c}-0.39 * * * \\
(0.12)\end{array}$ & $\begin{array}{c}-0.40 * * * \\
(0.12)\end{array}$ \\
\hline Balanced Budget Rule & $\begin{array}{c}0.91 * * \\
(0.40)\end{array}$ & $\begin{array}{r}0.71 * * \\
(0.30)\end{array}$ & $\begin{array}{l}0.76^{* *} \\
(0.32)\end{array}$ \\
\hline Debt Rule & $\begin{array}{c}0.11 \\
(0.40)\end{array}$ & $\begin{array}{c}0.24 \\
(0.32)\end{array}$ & $\begin{array}{c}0.15 \\
(0.32)\end{array}$ \\
\hline Right Executive & & & $\begin{array}{l}0.73 * * \\
(0.29)\end{array}$ \\
\hline Left Executive & & & $\begin{array}{l}-0.01 \\
(0.48)\end{array}$ \\
\hline Executive/Opposition ideology & & & $\begin{array}{l}0.22 * * \\
(0.10)\end{array}$ \\
\hline Constant & $\begin{array}{l}-1.46 \\
(0.45) \\
\end{array}$ & $\begin{array}{l}-1.36 \\
(0.47) \\
\end{array}$ & $\begin{array}{l}-1.31 \\
(0.51) \\
\end{array}$ \\
\hline Countries & 83 & 83 & 79 \\
\hline Observations & 1306 & 1300 & 1197 \\
\hline $\mathrm{R}^{2}$ (within) & 0.46 & 0.48 & 0.48 \\
\hline $\mathrm{R}^{2}$ (between) & 0.90 & 0.95 & 0.94 \\
\hline $\mathrm{R}^{2}$ (overall) & 0.64 & 0.70 & 0.70 \\
\hline
\end{tabular}

${ }^{*}$ - $\mathrm{p}<0.10 ; * *-\mathrm{p}<.05 ; * * * \mathrm{p}<0.01$

Consistent with past findings, the evidence in Table 1 suggests that levels of central government fiscal balances during the 1980-2012 period are largely determined by fiscal inertia, political and economic circumstances. As would be expected in Barro's tax smoothing framework, 
unemployment and debt service costs significantly reduce fiscal surplus's/increase deficits, while GDP growth has a robust and significant positive effect on fiscal balances. The number of parties appears to have significant temporal and intertemporal effects on fiscal balances. The negative temporal effects confirm past results regarding the ' $L$ aw of $1 / N$ ' where an increase in the number of meaningful actors (parties) in the budget process leads to larger deficit bias (common pool resource problem). This finding supports the findings of Volkerink and DeHaan (2001) who find that the effective number of parties and number of cabinet ministers generate significant positive effects on government debt accumulation in a sample of twenty-two OECD countries for the earlier 1971-1996 period. The positive intertemporal effects (interaction with lagged fiscal balances) suggest that an increase in meaningful actors in the budget process (veto players) decreases rates of adjustment or ability to implement large reforms (expansionary or contractionary). These results are consistent with past theoretical expectations and findings from Franzese (2007, 2010) and Blais et al (2010), where single party governments are free to pursue high magnitude expansionary or contractionary policy whereas multiparty governments face more pressure to converge on more watered down changes in fiscal balances. There is also evidence to support Persson and Svensson (1989) where conservative incumbents are expected to run lower deficits which tend to increase where there exists a liberal opposition, and; liberal governments expected to run higher deficits which tend to decrease given a conservative opposition. Column 3 of Table 1 suggests that right leaning executives will tend to run $0.73 \%$ lower deficits, and left wing governments will tend to run $0.01 \%$ higher deficits (both relative to center governments); however, where right/left executives are confronted by left/right leaning oppositions, these deficits will increase/decrease by $0.22 * 3=0.66 \%$. For example, if we assume that central leaning government tend to run a balanced budget, we would expect a right wing 
government, who believes that their most likely successor is of a similar ideology, will tend to run a $0.73 \%$ surplus, while a right wing government who believes that their successor is of a left leaning ideology will tend to run a $0.07 \%$ (0.73 - 0.66) surplus. Lastly, it appears that countries can dampen the effects of irresponsible fiscal policy by creating binding constraints in the form of a balanced budget rule. ${ }^{12}$ The magnitude of this effect on fiscal balances (between 0.71 and 0.91 percent of GDP) is more than sufficient to offset the indiscipline resulting from election year effects (between -0.37 and -0.40 percent of GDP).

While there appears to be a significant correlation between election years and central government fiscal balances, the planning horizons literature suggests that the 'true' effect on fiscal performance is generated through the expected probability of remaining in office in year $t+1$ rather than a simple binary indicator for whether an election or transition took place. It should be expected that, where an executive transition does take place with an a priori expected low likelihood of occurrence, these governments will be more likely to internalize the costs of future debt and generate lower deficits than incumbents who perceive a high a priori likelihood of a transition. In such cases, the estimates from (1) will be biased upwards as they assume that all transitions were fully known to those who left office. Past findings of significant election year effects (Debrun and Kumar 2007; Wehner 2010) may be a reflection of this probability, but like the binary transition indicator, is also measured with error. The inability to observe a continuous likelihood of executive transition, along with the potential for expected planning horizons to be incorporated into fiscal policy for a variety of reasons (see theoretical discussion), makes it likely that our binary election indicator in equation (1) may not generate accurate results.

\footnotetext{
${ }^{12}$ The author also ran a series of specifications interacting loss probabilities with fiscal rules (balanced budget) to test for any effects of conditional effects. None of these were significant.
} 
Based on the theoretical discussion in Section 2, the unobserved continuous likelihood of remaining in office should have a significant impact on the degree to which current policymakers internalize future burdens of irresponsible fiscal policy. From this, the error term in equation (1) will be correlated with this unobserved likelihood. To make this point clear, we can assume the 'true' equation for central government fiscal balances is:

$$
y_{i t}=\alpha_{i}+\lambda\left(\text { ptrans }_{i t}^{*}\right)+\boldsymbol{P}_{i t} \boldsymbol{\beta}+\boldsymbol{X}_{i t} \boldsymbol{\theta}+\varepsilon_{i t}
$$

Where ptrans $s_{i t}^{*} \sim[0,1]$ is the 'true' continuous unobserved probability of an executive transition in country $i$ at time $t$. Because ptrans $s_{i t}^{*}$ is a latent variable, equation (1) estimates the effect of executive planning horizons with some uncertainty $\left(\right.$ ptrans $\left._{i t}^{*}=\operatorname{elec}_{i t}+v_{i t}\right)$.

Substituting this back into equation (2) gives,

$$
y_{i t}=\alpha_{i}+\lambda\left(\text { elec }_{i t}+v_{i t}\right)+\boldsymbol{P}_{i t} \boldsymbol{\beta}+\boldsymbol{X}_{i t} \boldsymbol{\theta}+\varepsilon_{i t}
$$

suggesting that $\operatorname{cov}\left[\operatorname{elec}_{i t},\left(\varepsilon_{i t}-\lambda v_{i t}\right)\right]=-\lambda \sigma_{v}^{2} \neq 0$ which makes the parameter estimates from (1) [Table 1] inconsistent (Greene 2008; Wooldridge 2002).

In our sample of 83 countries over the 1980-2012 period, about half (51\%) of all elections result in an executive transition. From this, we would expect that the parameter estimate $\delta$ in (1) (and Table 1) to underestimate the true effect $\lambda$ from (2), as the former includes incidence where the likelihood of an executive transition is very low, giving the incumbent no incentive to create a future burden than they themselves will have to bear. With the additional possibility that governments may use fiscal policy as a device to increase their popularity in closely contested election, there may also exist a non-linear relationship between transition probabilities and fiscal performance. Prior to addressing this problem, however, it is important to define ptrans.. 
To get a more accurate estimate for ptrans ${ }_{i t}^{*}$, we can begin with the work of Kayser and Lindstadt (2015). As noted in the data section, the authors measure electoral risk as a function of, $i$ ) the expected variability in party level vote share, and $i i$ ) the district level seat-vote elasticities (which are one-for-one transformations in PR systems). The advantage of this approach is the ability to easily estimate the likelihood of electoral defeat/victory which "enjoys exogeneity from potential policy related dependent variables" (Kayser and Lindstadt 2015). It is important to note, however, that the Kayser-Lindstadt (KL) measure is one of plurality swings, rather than executive transitions, but the two will likely be correlated. For example, as noted in the paper, "In a two party system, losing plurality status in parliament almost inevitably means leaving government, while in multi-party [or non-democratic] systems with coalition governments, this is not necessarily the case." ${ }^{13}$ So, while Kayser-Lindstadt are fundamentally interested in "the expected probability that a plurality party in parliament losses it's seats plurality in the next election", this paper is interested in the expected probability of a change in the executive branch of government at any point in time during their tenure (even if an election does not occur). Computing KL for a broader sample of countries, therefor, requires us to assume that all executives form expectations about their future tenure based, to some degree, on the degree of formal political opposition they face (vote shares). The advantage of this approach is the ability to examine executive transitions in a more dynamic environment which includes both election and nonelection years from a globally representative sample of countries.

The disadvantage that comes with broadening the population/sample is not having the manpower to compile district level vote-seat data which is required to estimate swing sensitivity in multiparty systems (Linzer 2012; Kayser and Lindstadt 2015). One of the most pronounced

\footnotetext{
${ }^{13}$ Kayser and Lindstadt (2015), p.244
} 
challenges is the relatively small domains on which aggregate kernel densities fall. ${ }^{14}$ The implications of this are narrower estimates of loss probabilities, where a larger proportion of elections will be predicted to effectively have a zero probability of a plurality shift (which may be true). If we assume that expected plurality shift likelihoods are good exogenous representatives of executive transitions $\left(\right.$ ptrans $\left._{i t}^{*} \approx p p l u r_{i t}\right)$, their effect on central government balances can be directly estimated in two ways: ${ }^{15}$

$$
\begin{gathered}
y_{i t}=\alpha_{i}+\lambda\left(\text { pplur }_{i t}\right)+\boldsymbol{P}_{\boldsymbol{i t}} \boldsymbol{\beta}+\boldsymbol{X}_{\boldsymbol{i t}} \boldsymbol{\theta}+\varepsilon_{i t} \\
y_{i t}=\alpha_{i}+\lambda_{1}\left(\text { pplur }_{i t}\right)+\lambda_{2}\left(\text { pplur }_{i t}\right)^{2} \boldsymbol{P}_{\boldsymbol{i t}} \boldsymbol{\beta}+\boldsymbol{X}_{\boldsymbol{i t}} \boldsymbol{\theta}+\varepsilon_{i t}
\end{gathered}
$$

The first specification (4a) includes a linear effect of vote swings which assumes that incumbents base fiscal decisions based on their discount factors associated with expectations about remaining in office in the future. The second specification (4b) allows for the possibility that incumbent will use fiscal policy as an instrument to increase their levels of support in tightly competitive situations. In this second case, we would expect deficit spending to be highest where pplur $_{i t}^{*}$ is close to $50 \%$.

Table 2 below shows estimates for equations (4a) and (4b) with the KL district level data for sample of 21 countries over the 1980 - 2008 period (columns 1 and 2), and versions $a$ ) and $b$ ) of pplur $_{i t}$ (discussed above) computed from aggregate level data in our sample of 79 countries $^{16}$ over the 1980-2012 period (columns 3 - 6). Columns 1, 3, and 5 show the linear effects of loss

\footnotetext{
${ }^{14}$ Ibid.

${ }^{15} \mathrm{pig}_{i t}$ is included in $\boldsymbol{P}$.

${ }^{16}$ Single party countries were coded as pplur $_{i t}=0$.
} 
probabilities on fiscal balances from (4a), while; columns 2, 4, and 6, show the quadratic effects from (4b).

Table 2: Central Government Balances and Loss-Likelihoods (1980-2012) (Fixed effects with cluster robust standard errors in parenthesis)

\begin{tabular}{|c|c|c|c|c|c|c|}
\hline \multirow[t]{3}{*}{ Variables } & \multicolumn{2}{|c|}{$\begin{array}{l}\text { K-L District Level } \\
\text { Sample }\end{array}$} & \multicolumn{2}{|c|}{ Aggregate Sample (a) } & \multicolumn{2}{|c|}{ Aggregate Sample (b) } \\
\hline & linear & Quadratic & linear & quadratic & linear & quadratic \\
\hline & (1) & (2) & (3) & (4) & (5) & $(6)$ \\
\hline $\begin{array}{l}\text { Central Government Surplus/Deficit } \\
(\mathrm{t}-1) \\
(\% G D P)\end{array}$ & $\begin{array}{c}0.78 * * * \\
(0.03)\end{array}$ & $\begin{array}{l}0.78^{* * * *} \\
(0.03)\end{array}$ & $\begin{array}{c}0.51 * * * \\
(0.05)\end{array}$ & $\begin{array}{c}0.51 * * * \\
(0.05)\end{array}$ & $\begin{array}{c}0.50 * * * \\
(0.05)\end{array}$ & $\begin{array}{c}0.51 * * * \\
(0.05)\end{array}$ \\
\hline $\begin{array}{l}\text { Central Government Surplus/Deficit } \\
(\mathrm{t}-1)^{*} \text { Parties in Government }\end{array}$ & $\begin{array}{c}0.02 \\
(0.02)\end{array}$ & $\begin{array}{c}0.02 \\
(0.02)\end{array}$ & $\begin{array}{c}0.09^{* * *} \\
(0.03)\end{array}$ & $\begin{array}{c}0.09^{* * * *} \\
(0.02)\end{array}$ & $\begin{array}{c}0.09^{* *} \\
(0.02)\end{array}$ & $\begin{array}{c}0.09 * * * \\
(0.02)\end{array}$ \\
\hline GDP growth & $\begin{array}{c}0.36^{* * * *} \\
(0.08)\end{array}$ & $\begin{array}{c}0.36^{* * * *} \\
(0.08)\end{array}$ & $\begin{array}{c}0.24 * * * \\
(0.03)\end{array}$ & $\begin{array}{c}0.24 * * * \\
(0.03)\end{array}$ & $\begin{array}{c}0.24 * * * \\
(0.03)\end{array}$ & $\begin{array}{c}0.24 * * * \\
(0.03)\end{array}$ \\
\hline Inflation (ln) & $\begin{array}{l}-0.11 \\
(0.14)\end{array}$ & $\begin{array}{l}-0.11 \\
(0.14)\end{array}$ & $\begin{array}{c}0.12 \\
(0.10)\end{array}$ & $\begin{array}{c}0.12 \\
(0.10)\end{array}$ & $\begin{array}{c}0.12 \\
(0.10)\end{array}$ & $\begin{array}{c}0.12 \\
(0.10)\end{array}$ \\
\hline Unemployment & $\begin{array}{l}-0.04 \\
(0.07)\end{array}$ & $\begin{array}{l}-0.04 \\
(0.07)\end{array}$ & $\begin{array}{c}-0.10^{* *} \\
(0.04)\end{array}$ & $\begin{array}{c}-0.10^{* *} \\
(0.04)\end{array}$ & $\begin{array}{c}-0.10^{* *} \\
(0.04)\end{array}$ & $\begin{array}{c}-0.10^{* *} \\
(0.04)\end{array}$ \\
\hline Real Interest Rate & $\begin{array}{l}-0.08 \\
(0.11)\end{array}$ & $\begin{array}{l}-0.08 \\
(0.11)\end{array}$ & $\begin{array}{l}-0.02 \\
(0.02)\end{array}$ & $\begin{array}{l}-0.01 \\
(0.02)\end{array}$ & $\begin{array}{l}-0.01 \\
(0.02)\end{array}$ & $\begin{array}{l}-0.01 \\
(0.02)\end{array}$ \\
\hline Parties in Government & $\begin{array}{l}-0.03 \\
(0.13)\end{array}$ & $\begin{array}{l}-0.03 \\
(0.13)\end{array}$ & $\begin{array}{c}-0.22 * * \\
(0.10)\end{array}$ & $\begin{array}{c}-0.22 * * \\
(0.10)\end{array}$ & $\begin{array}{c}-0.22 * * \\
(0.10)\end{array}$ & $\begin{array}{c}-0.22 * * \\
(0.10)\end{array}$ \\
\hline KL Loss Probability & $\begin{array}{l}-0.64 \\
(0.74)\end{array}$ & $\begin{array}{l}-1.30 \\
(0.82)\end{array}$ & $\begin{array}{c}-0.86^{* * *} * \\
(0.31)\end{array}$ & $\begin{array}{c}-3.10 * * \\
(1.24)\end{array}$ & $\begin{array}{c}-0.75^{* *} \\
(0.35)\end{array}$ & $\begin{array}{l}-1.31 \\
(1.06)\end{array}$ \\
\hline KL Loss Probability Sq. & & $\begin{array}{c}1.28 \\
(2.27)\end{array}$ & & $\begin{array}{l}3.23 * * \\
(1.59)\end{array}$ & & $\begin{array}{l}0.78 \\
1.55\end{array}$ \\
\hline Balanced Budget Rule & $\begin{array}{c}0.65 \\
(0.45)\end{array}$ & $\begin{array}{c}0.67 \\
(0.44)\end{array}$ & $\begin{array}{c}0.76^{* *} \\
(0.33)\end{array}$ & $\begin{array}{c}0.77 * * \\
(0.30)\end{array}$ & $\begin{array}{c}0.75^{* *} \\
(0.33)\end{array}$ & $\begin{array}{c}0.75^{* *} \\
(0.33)\end{array}$ \\
\hline Debt Rule & $\begin{array}{l}-0.36 \\
(0.51)\end{array}$ & $\begin{array}{l}-0.39 \\
(0.52)\end{array}$ & $\begin{array}{c}0.15 \\
(0.32)\end{array}$ & $\begin{array}{c}0.18 \\
(0.32)\end{array}$ & $\begin{array}{c}0.14 \\
(0.32)\end{array}$ & $\begin{array}{c}0.16 \\
(0.32)\end{array}$ \\
\hline Right Executive & $\begin{array}{c}0.38 \\
(0.34)\end{array}$ & $\begin{array}{c}0.39 \\
(0.34)\end{array}$ & $\begin{array}{c}0.74 * * \\
(0.29)\end{array}$ & $\begin{array}{c}0.77 * * \\
(0.29)\end{array}$ & $\begin{array}{c}0.76^{* *} \\
(0.29)\end{array}$ & $\begin{array}{c}0.76^{* *} \\
(0.29)\end{array}$ \\
\hline Left Executive & $\begin{array}{c}0.34 \\
(0.52)\end{array}$ & $\begin{array}{c}0.34 \\
(0.52)\end{array}$ & $\begin{array}{c}0.03 \\
(0.48)\end{array}$ & $\begin{array}{c}0.07 \\
(0.49)\end{array}$ & $\begin{array}{c}0.01 \\
(0.49)\end{array}$ & $\begin{array}{c}0.02 \\
(0.49)\end{array}$ \\
\hline Executive/Opposition Ideology & $\begin{array}{c}0.02 \\
(0.12)\end{array}$ & $\begin{array}{c}0.03 \\
(0.12)\end{array}$ & $\begin{array}{c}0.22 * * \\
(0.10)\end{array}$ & $\begin{array}{c}0.21 * * \\
(0.10)\end{array}$ & $\begin{array}{c}0.23 * * \\
(0.10)\end{array}$ & $\begin{array}{c}0.23 * * \\
(0.10)\end{array}$ \\
\hline Constant & $\begin{array}{l}-1.11 \\
(0.82)\end{array}$ & $\begin{array}{l}-1.11 \\
(0.82)\end{array}$ & $\begin{array}{l}-1.38 \\
(0.51)\end{array}$ & $\begin{array}{l}-1.38 \\
(0.50)\end{array}$ & $\begin{array}{c}-1.36 * * \\
(0.52)\end{array}$ & $\begin{array}{c}-1.35^{* * *} \\
(0.52)\end{array}$ \\
\hline Countries & 21 & 21 & 79 & 79 & 79 & 79 \\
\hline Observations & 425 & 425 & 1197 & 1197 & 1197 & 1197 \\
\hline$R^{2}$ (within) & 0.68 & 0.68 & 0.47 & 0.48 & 0.47 & 0.47 \\
\hline$R^{2}$ (between) & 0.93 & 0.93 & 0.94 & 0.94 & 0.94 & 0.94 \\
\hline$R^{2}$ (overall) & 0.82 & 0.82 & 0.71 & 0.71 & 0.70 & 0.70 \\
\hline
\end{tabular}


These results are relatively consistent with our baseline findings in Table 1 where fiscal inertia, economic circumstances, veto players, and ideological polarization appear to be strong and robust predictors of central government fiscal balances. The first two columns show results using the KL data for a sample of 21 countries. With respect to loss-likelihoods, the results here are relatively uninformative which could be due to the smaller sample sizer or difference in measure measurement discussed above. In order to isolate the reason for these insignificant results, we rerun the regressions from columns 1 and 2, replacing the original KL data with the modified KL data for the same sample of countries. As can be seen in appendix A, the results are mixed suggesting that there could actually be some merit in working with narrower densities from aggregate data. ${ }^{17}$ The loss likelihood results for our aggregate KL measure appears to have a statistically significant linear relationship with fiscal outcomes (central government balances) in our full sample of 79 countries providing evidence of a discount effect from executives who form fiscal policy based on expectations of remaining in office. The magnitude of this linear effect ranges between $0.64 \%$ and $1.05 \%$ higher deficits (as a percent of GDP) when comparing an executive who fully expects to remain in office relative to an executive who fully expects to lose it (ceteris paribus). These results suggest that the continuous unobserved likelihood of expected executive planning horizons ( ptrans $_{i t}^{*}$ ) are significantly correlated with fiscal balances and differ in magnitude from those estimated in (1) where this probability was measured with error $\left(e l e c_{i t}=p\right.$ trans $\left._{i t}^{*}+v_{i t}\right)$. There is also some evidence of a quadratic effect from our full sample of countries where deficits tend to be highest where the expected likelihood of a plurality swing are close to fifty percent. We can see this by setting the first derivative of $y$ with respect to pplur from column (4) in Table 2 equal to zero,

\footnotetext{
${ }^{17}$ See Appendix A.
} 


$$
\frac{\partial y}{\partial p p l u r}=-3.1+6.46(\text { pplur })=0 \Rightarrow \text { pplur }^{*}=\frac{3.1}{6.46} \approx 0.48
$$

suggesting that deficits will reach their highest point when the likelihood of a plurality shift is around 48 percent. Figure 2 shows the predicted relationship between the unobserved probability of an executive transition and fiscal performance measured as central governments surplus/deficit as a percentage of GDP from the third and fourth columns of Table 3 (using linear and quadratic loss probabilities). Both functional forms predict a statistically significant correlation between the likelihood of remaining in office and fiscal balances with somewhat greater robustness coming from the linear estimates.

Figure 2: Fiscal Performance and Loss Likelihoods (Linear and Quadratic)

(la: linear)

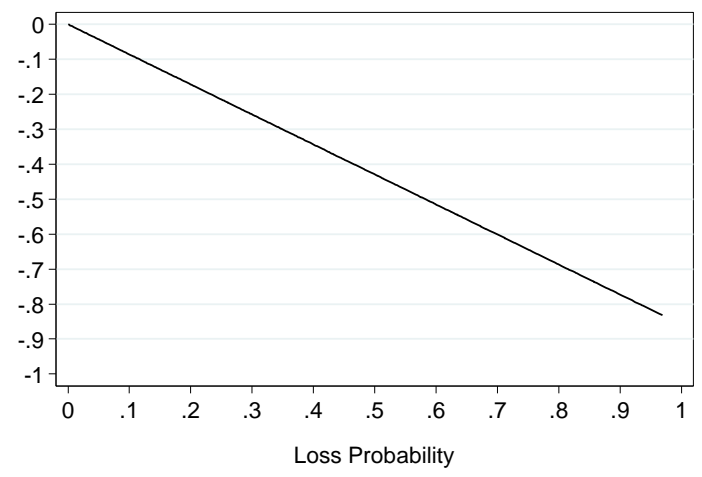

Estimates are calculated from column 3 of Table 2 (1b: quadratic)

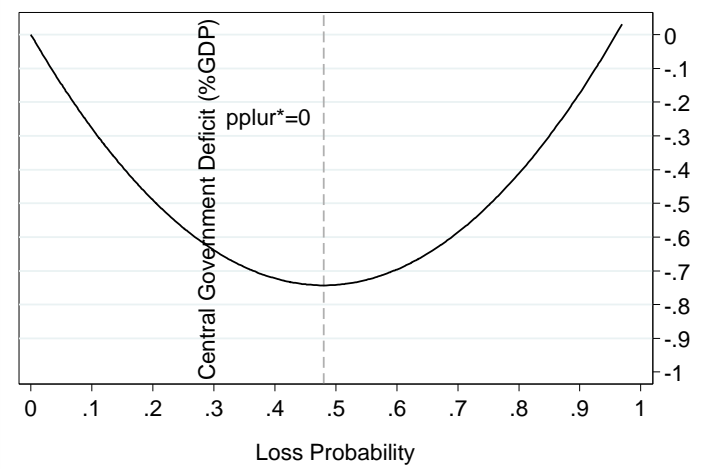

Estimates are calculated from column 4 of Table 2

Source: author's calculation from Table 2

Lastly, it appears that the existence of a balanced budget rule can help to offset negative effects from distortionary temporal and intertemporal effects on fiscal outcomes. The magnitude of this independent effect ranges between $0.66 \%$ and $0.77 \%$ of GDP, which is nearly sufficient to offset the distortionary effects from an incumbent who knows that they will lose office with a probability near one (estimated in our linear specifications as ranging between 0.64 and 1.05). With respect to a dampening effect on the political business cycle which has been found in past research 
on US states (see Rose 2006), we run a separate set of both linear and quadratic equations with interactions with the existence of balanced budget and debt rules. ${ }^{18}$

Table 3: Dampening Effects of Fiscal Rules?

(Fixed effects with cluster robust standard errors in parenthesis)

\begin{tabular}{r|cc|cc}
\hline \multirow{2}{*}{ Variables } & \multicolumn{2}{|c|}{ Aggregate Sample (a) } & \multicolumn{2}{c}{ Aggregate Sample (b) } \\
\cline { 2 - 5 } & linear & quadratic & linear & quadratic \\
\hline KL Loss Probability & $-1.04^{* *}$ & -3.39 & -0.57 & -0.39 \\
& $(0.45)$ & $(2.12)$ & $(0.49)$ & $(1.52)$ \\
KL Loss Probability Sq. & & 3.30 & & -0.27 \\
& & $(2.64)$ & & $(2.23)$ \\
Balanced Budget Rule & $0.74^{* *}$ & $0.74^{* *}$ & $0.77^{* *}$ & $0.78^{* *}$ \\
& $(0.33)$ & $(0.33)$ & $(0.34)$ & $(0.33)$ \\
Debt Rule & 0.13 & 0.13 & 0.18 & 0.18 \\
& $(0.32)$ & $(0.32)$ & $(0.34)$ & $(0.34)$ \\
KL Loss Probability*BBR & 0.28 & 1.07 & -0.08 & -2.33 \\
& $(0.71)$ & $(2.56)$ & $(0.81)$ & $(2.68)$ \\
KL Loss Probability & & -1.23 & & 3.27 \\
Sq*BBR & & $(3.33)$ & & $(4.25)$ \\
$K L$ Loss Probability*DR & 0.23 & -1.06 & -0.55 & 0.28 \\
& $(0.63)$ & $(2.35)$ & $(0.80)$ & $(2.72)$ \\
KL Loss Probability & & 2.55 & & -1.21 \\
Sq*DR & & $(3.22)$ & & $(4.15)$ \\
\hline Countries & 79 & 79 & 79 & 79 \\
observations & 1197 & 1197 & 1197 & 1197 \\
\hline$R^{2}$ (within) & 0.47 & 0.47 & 0.47 & 0.47 \\
$R^{2}$ (between) & 0.94 & 0.94 & 0.94 & 0.94 \\
$R^{2}$ (overall) & 0.71 & 0.71 & 0.70 & 0.70 \\
\hline
\end{tabular}

The results in Table 3 suggest that, while the existence of a balanced budget rule continues to have an independent effect on fiscal performance, there is not a great deal of evidence suggesting an interactive dampening effect from either balanced budget or debt rules.

Relating these results back to our theoretical discussion from Section 2, it appears that there are several political/institutional factors which influence budgetary outcomes. Firstly, an increase in the number of meaningful actors in the budget process (parties in government) will lead to a larger deficit bias, along with a dampening effect any expansionary/contractionary initiatives.

\footnotetext{
${ }^{18}$ Note: the specification is the same as in equations (4a) and (4b). Only result for parameter estimates of interest are shown in Table 3.
} 
These results are generally consistent with the theoretical expectations from past literature (Franzese 2007, 2010; Blais et al 2010). Second, executive and opposition ideology both seem to have an impact on fiscal outcomes to the extent that surplus generating conservative executives will reduce these surpluses when confronted by liberal opposition (vice versa for liberal executives confronted by conservative opposition). These, previously untested, results are consistent with the theoretical expectations from Persson and Svensson (1989). Thirdly, incumbent executives will take into account the continuous expected likelihood of remaining in office when making current fiscal decisions to the extent that, executives who fully expect to remain in office will tend to run lower deficits/higher surpluses that executives who expect to compete for power. Relating this back to the theoretical discussion form Section 2, there is some evidence to support incumbents as strategic actors who will use deficit financing to influence tight elections, but may return to more responsible fiscal planning where they are certain to lose power (right hand side of Figure 2). The more robust linear effects from columns 3 and 5, however, suggest that incumbent discount factors linearly determine their level of fiscal responsibility, to the extent that the most responsible fiscal outcomes will come from those who are certain they will always be in power.

\section{Conclusion}

Persistence negative imbalances since the 1970's has led the academic community to search for the causes of unsustainable fiscal imbalances, and potential institutional remedies which might structurally induce socially optimal outcomes. Evidence in this paper is found confirming Barro's tax smoothing hypothesis, where distortionary burdens are minimized over time with pro and counter-cyclical stabilizers, along with the temporal and intertemporal distortions created through the veto player hypothesis which predicts that the number of actors in the budget 
formulation process will significantly impact the magnitude of year-on-year flexibility which policymakers possess to make fiscal adjustments. While these macroeconomic stabilization and veto player/common pool resource findings are consistent with a considerable amount of established literature, less emphasis has been given to the finite planning horizons of policymakers.

Existing theoretical contributions have predicted that policymakers, who heavily discount the future, will fail to internalize any increases in debt which they can pass off to future administrations, effectively constraining their policy choice set. The empirical validity of these theoretical expectations has, however, been given limited empirical attention due to the difficulties associated with measuring the unobserved discount factors of policymakers and the potential for non-linear relationships between fiscal performance and these latent probabilities. Characterizing these discount factor, or the likelihood of remaining in office, as a binary indicator of an election taking place fails to recognize that incumbents evaluate their chances of remaining in office probabilistically. Consistent with these theoretical expectations, this paper finds that as the unobserved expected probability of policymakers remaining in office decreases, so too does the level with which they internalize the future burdens of fiscal imbalances, to the extent that incumbent who know with certainty in time $t$ that they will no longer be in office in time $t+1$ will generate between $0.64 \%$ and $1.05 \%$ higher fiscal deficits (as a \% of GDP) in their final year in power than those who know with certainty that they will remain in office (ceteris paribus). There is, however, some evidence suggesting that this deficit spending may be more reserved for strategic purposes, where incumbents will be most inclined to high deficits where they face tight competition to maintain control of the executive. 
The general findings suggest that institutional structure, as well as the objective functions of policymakers, do play a significant role in determining fiscal outcomes. While institutional problems can be resolved by concentrating power in a small number of ideologically homogeneous actors who fully internalize the costs of their budgetary decisions, the problem of uncertain tenure strikes deeper at the heart of the constitutional framework under which these actors function. The goal then is to devise a mechanism within the institutional bounds of a democratic system which overcomes a problem directly associated with its core. 


\section{References}

Alesina, A., Hausmann, R. Homes, R. and Stein E., (1999) Budget Institutions and Fiscal Performance in Latin America. Journal of Development Economics 59: 253-273

Alesina, A. and Perotti, R. (1995) The Political Economy of Budget Deficits. International Monetary Fund Staff Papers, 42 (1)

Alesina, A. and Tabellini, G. (1990) A Positive Theory of Fiscal Deficits and Government Debt. Review of Economic Studies, 57 (3): 403-414

Alesina A. and Tabellini, G. (1988) Voting on the Budget Deficit. NBER working paper no.2759

Alt, J.E. and Lassen, D. D. (2006) Transparency, Political Polarization, and Political Budget Cycles in OECD Countries. American Journal of Political Science Vol. 50( 3): 530 - 550

Alt, J.E. and Lowry, R.C. (1994) Divided Government, Fiscal Institutions and Budget Deficits: Evidence from the States. The American Political Science Review 88 (4): 811-828

Alt, J.E. and Rose, S.S. (2009). Context Conditional Political Business Cycles. The Oxford Handbook of Comparative Politics (Boix, C. and Stokes, S. (ed)). Oxford University Press, 2015.

Barro, R. J. (1973) The Control of Politicians: An Economic Model. Public Choice, 14 (1): 19-42

Barro, R.J. (1979) On the Determination of Public Debt. Journal of Political Economy, 87 (5): $940-971$

Barro, R.J. (1989) The Ricardian Approach to Budget Deficits. The Journal of Economic Perspectives $3(2): 37-54$

Baum, C. F., Schaffer, M.E. and Stillman, S. (2003) Instrumental Variables and GMM: Estimation and Testing. The Stata Journal, 3 (1): 1-31

Baxter, M. and King, R.G. (1993) Fiscal Policy in General Equilibrium. The American Economic Review 83 (3): 315-334

Besley, T. And Case, A. (1995) Does Electoral Accountability Affect Economic Policy Choices? Evidence from Gubernational Term Limits. The Quarterly Journal of Economics, 110 (3): 769798

Besley, T. and Case, A. (1995) Incumbent Behavior: Vote Seeking, Tax Setting, and Yardstick Competition. The American Economic Review: 25-45 
Blais, A. et al. (2010). Public Spending, Public Deficits and Government Coalitions. Political Studies 58 (5): $829-846$

Blejer, M. I. And Cheasty, A. (1991) The Measurement of Fiscal Deficits: Analytical and Methodological Issues. Journal of Economic Literature, 29 (4): 1644-1678

Boskin, M. J. (1988) Consumption, Saving, and Fiscal Policy. The American Economic Review, 78 (2): $401-407$

Box-Seffensmeier, J.M. and Jones, B. S. (1997) Time is of the Essence: Event History Models in Political Science. American Journal of Political Science 41 (4): 1414-1461

Buchanan, J.M. and Lee, D.R. (1982) Politics, Time and the Laffer Curve. The Journal of Political Economy 90 (4): 816-819

Carey, J. M. (1996) Term Limits and Legislative Representation. Cambridge University Press.

Chang, E. C. C. and Tsebelis, G. (2004) Veto Players and the Structure of Budgets in Advanced Industrialized Countries. European Journal of Political Research, 43: 449-476.

Cukierman, A. and Meltzer, A.H. (1989) A Political Theory of Government Debt and Deficits in a Neo-Ricardian Framework. The American Economic Review 79 (4): 713-732

Debrun, X. and Kumar, M.S. (2007) The Discipline Enhancing Role of Fiscal Institutions: Theory and Empirical Evidence. International Monetary Fund Working Paper WP/07/171

De Haan, J. and Sturm, J. E. (1997) Political and Economic Determinants of OECD Budget Deficits and Government Expenditures: A Reinvestigation. European Journal of Political Economy 13: $739-750$

De Haan, J. and Volkerink, B. (2001) Fragmented Government Effects on Fiscal Policy: New Evidence. Public Choice 109: 221-242

Devereux, M. B. and Wen, J. F. (1998) Political Instability, Capital Taxation, and Growth. European Economic Review 42: 1635-1651

Dewan, T. and Myatt, D. P. (2010) The Declining Talent Pool of Government. American Journal of Political Science 54(2): 267-286 
Edin, P.A. and Ohlsson, H. (1991) Political Determinants of Budget Deficits: Coalition Effects versus Minority Effects. European Economic Review 35: 1597-1603

Edwards, S. and Tabellini, G. (1991) The Political Economy of Fiscal Policy and Inflation in Developing Countries: An Empirical Analysis. Policy Research Working Paper. World Bank. Washington, DC.

Eisner, R. (1989) Budget Deficits: Rhetoric and Reality. The Journal of Economic Perspectives 3(2): 73-93

Favero, C. and Giavazzi, F. (2007) Debt and the Effects of Fiscal Policy. Federal Reserve Bank of Boston Working Paper No. 07-4

Ferejohn, J. and K. Krehbiel (1987) The Budget Process and the Size of the Budget. American Journal of Political Science 31(2): 296-320

Franzese, R. J. (2007) Fiscal Policy with Multiple Policymakers: Veto Actors and Deadlock; Collective Action and Common Pools; Bargaining and Compromise. Veto Players and Policy Change, Hideko Magara, ed., pp. 118-161, Waseda University Press

Franzese, R. J. (2010). The Multiple Effects of Multiple Policymakers: Veto Actors Bargaining in Common Pools. Rivista Italiana di Scienza Politica 40(3): 341-370

Hallerberg, M., Strauch, R. and Von Hagen, J. (2007) The Design of Fiscal Rules and Forms of Governance in European Union Countries. European Journal of Political Economy, 23: 338359

Hallerberg, Mark, Rolf Strauch, and Jürgen von Hagen (2009). Fiscal Governance in Europe. Cambridge, Cambridge University Press.

Heckman, J.J. (1978) Dummy Endogenous Variables in a Simultaneous Equation System. Econometrica 46 (4): 931-959

International Monetary Fund (2012). Fiscal Rules at a Glance: Country Details from a New Dataset. Prepared by Nina Budina, Tidiane Kinda, Andrea Schaechter, and Anke Weber. IMF Working Paper 12/273

International Monetary Fund (2014) Fiscal Rules Dataset. Fiscal Affairs Department, International Monetary Fund, Washington, DC. 
International Monetary Fund (2015). Fiscal Rules at a Glance. IMF Background Paper. Prepared by Elva Bova, Tidiane Kinda, Priscilla Muthoora, and Frederik Toscani. International Monetary Fund, Washington, DC.

International Monetary Fund (2017) Fiscal Rules at a Glance. IMF Background Paper. Prepared by Victor Lledó, Sungwook Yoon, Xiangming Fang, Samba Mbaye, and Young Kim. International Monetary Fund, Washington, DC.

International Monetary Fund (1990-2010). Government Finance Statistics Yearbook. Washington: International Monetary Fund

International Monetary Fund (2001) Government Finance Statistics Manual 2001 (GFSM 2001). Statistics Department, International Monetary Fund

International Monetary Fund (2014) Government Finance Statistics Manual 2014 (GFSM 2014).

Statistics Department, International Monetary Fund

International Monetary Fund (2011) International Financial Statistics Yearbook. Washington: International Monetary Fund

Johnsen, C., Shepsle, K.A. and Weingast, B. (1981) The Political Economy of Benefits and Costs: A Neoclassical Approach to Distributive Politics Journal of Political Economy 89(4): 642-664

Kayser, M. A. and Lindstadt, R. (2015). A Cross-National Measure of Electoral Competitiveness. Political Analysis 23(2): 242-253

Kontopoulos, Y. and Perotti, R. (2002) Fragmented Fiscal Policy. Journal of Public Economics 86: $191-222$

Milesi-Ferretti, G. M. and Spolaore, E. (1994) How Cynical can an Incumbent be? Strategic Policy in a model of Government Spending. Journal of Public Economics 55: 121-140

Musgrave, R. A. and Musgrave, P. B. (1973) Public Finance in Theory and Practice. McGraw-Hill Inc. New York, USA

Newey, W.K. (1987) Efficient Estimation of Limited Dependent Variable Models with Endogenous Explanatory Variables. Journal of Econometrics 36: 231-250

Persson, T., Roland, G. And Tabellini, G. (2000) Comparative Politics and Public Finance. The Journal of Political Economy 108 (6): 1121-1161 
Persson, T. and Tabellini, G. (2003) The Economic Effect of Constitutions. MIT Press Cambridge, MA, USA

Persson, T. And Svensson, L.E.O. (1989) Why a Stubborn Conservative would Run a Deficit: Policy with Time-Inconsistent Preferences. The Quarterly Journal of Economics, 104 (2): 325-345

Poterba, J.M. (1996) Budget Institutions and Fiscal Policy in the U.S. States. The American Economic Review 86 (2): 395-400

Rabe-Hesketh, S. and Skrondal, A. (2005) Multilevel and Longitudinal Modelling using Stata. StataCorp LP, College Station, Texas

Raymond, N. and Stuart, C. (1984) Short Run Politicians and Long Run Tax Revenue: An Empirical Assessment. The Scandinavian Journal of Economics 86 (3): 314-325

Rogoff, K. and Sibert, A. (1988) Elections and Macroeconomic Policy Cycles. The Review of Economic Studies 55 (1): 1-16

Rose, S. (2006) Do Fiscal Rules Dampen the Political Business Cycle? Public Choice 128: 407

Roubini, N. and Sachs, J.D. (1989) Political and Economic Determinants of Budget Deficits in the Industrial Democracies. European Economic Review 33: 903-938

Schaffer, M.E. (2010) xtivreg2: Stata module to perform extended IV/2SLS, GMM and AC/HAC, LIML and k-class Regression for Panel Data Models http://ideas.repec.org/c/boc/bocode/ $\underline{\text { s456501.html }}$

Stiglitz, J.E. (1989) The Economic Role of the State. Oxford: Basil Blackwell Press

Stratmann, T. (2012) The Effects of Earmarks on the Likelihood of Reelection. European Journal of Political Economy 32: 341-355 .

Testa, C. (2010) Party Polarization and Electoral Accountability. Polarization and Conflict Project CIT. European Commission

Tridimas, G. and Winer, S.L. (2005) A Contribution to the Political Economy of Government Size: 'Demand', 'Supply' and 'Political Influence'. European Journal of Political Economy 21 (3): $643-666$ 
Wehner, J. (2010) Cabinet Structure and Fiscal Policy Outcomes. European Journal of Political Research 49: 631-653

Wehner, J. (2010) Institutional Constraints on Profligate Politicians: The Conditional Effect of Partisan Fragmentation on Budget Deficits. Comparative Political Studies, 43 (3): 208-229

Yellen, J.L. (1989) Symposium on the Budget Deficit. The Journal of Economic Perspectives 3 (2): $17-21$

Zupan, M.A. (1990) The Last Period Problem in Politics: Do Congressional Representatives not subject to a Reelection Constraint Alter their Voting Behaviour? Public Choice 65: 167-180 